\title{
The natural environment for the experimental study of phonosemantics
}

Elena Shamina

Department of Phonetics, Saint Petersburg State University, Russia

https://doi.org/10.36505/ExLing-2019/10/0048/000408

\begin{abstract}
It is claimed that the most natural environment for experimental phonosemantic studies is that of the minimal text in the respondents' native language with the use of real (native or foreign) lexis in its sound form. The claim is based on the idea that if language is viewed as the tool for cognition and communication, then its units, including iconic ones, realize their functions in all their entirety exclusively in a verbal (originally oral) context, while iconic non-language vocalizations or pseudowords serve only as evidence of such psycho-physiological phenomena as synesthesia and synesthemia. The results of the perceptual experiment with English and Russian speakers seem to point to the validity of the claim. Key words: phonosemantics, natural language units, linguistic context.
\end{abstract}

Key words: phonosemantics, Russian, native/foreign language

\section{Background: phonosemantics}

The sound form of iconic language signs, sound imitative or sound symbolic ones, (unlike indices or symbols in Peirce's classification (1994)) represents at least some, though definitely not all, components of their meaning. As their functioning is based on universal cognitive principles (Fodor 1975) and psychological and neuro-physiological foundations, such as synesthesia (Горелов 2003) and synesthemia (Воронин 1982) they may be supposed to have cognitive potential and to provoke correct perception and understanding of foreign words.

\section{Background: experimental studies}

Experimental studies of phonosemantics that have a long and notable history dating back almost a century (cf. (Köhler 1929) may be said to have been mixing language and non-language environment for the procedure. Very few of them have relied on perception and evaluation of the linguistic icons in context. The methods have varied, including not only simple matching or translation, but also highly standardized numerical ones (Osgood et al 1967). Different types of material have been used: separate speech sounds, graphemes (Журавлев 1974), pseudo-words (Köhler 1929; Горелов 2003), non-language vocalizations (Perlman, Lupyan 2018) and lexis of existing natural languages (Osgood et al 1967). Representation of meaning has been offered to the

ExLing 2019: Proceedings of 10 $0^{\text {th }}$ International Conference of Experimental Linguistics, 25-27 September 2019, Lisbon, Portugal 
subjects with the help of pictures, abstract figures, descriptions and words of the subjects' native tongues or foreign languages. It is worthy of notice that none of these is a regular feature of natural language communication. That is probably why there are instances when the assumed general phonosemantic correspondences between sound and meaning do not come true in a particular language (Syles, Gawne 2017).

Synesthesia and synesthemia may be part of the human psychological and neuro-physiological mechanisms, but the question still remains if they play a significant role in communication in a living language. If language should be viewed as the tool for cognition and communication, then its units, including iconic ones, realize their functions in all their entirety exclusively in a verbal context, presumably in the oral form. This observation sets certain restrictions on the format of the phonosemantic experiments to create the most natural environment for the study.

\section{Perception of foreign words in a native language context Experiment design}

The experiments were specifically designed to ensure that the subjects dealt with linguistic instances in their sound form, and not just any acoustic or visual stimuli.

They were exposed to utterances in their native tongue that they could see in writing and asked to fill in the gaps by picking one out of the two foreign words presented to them in the (pre-recorded) audio form, e.g., A. Leaves began to ...(1 свистеть / 2 шелестеть)... and a door ...(1 звенеть / 2 грохать)... shut, B. Bce девушки обсуждали, как закадрить самьъх...(1 gитр / 2 ұing)... мальчиков на курсе. The respondents were speakers of Russian and English, of both sexes and of various social and age groups, 82 and 103 people respectively, who did not know the language of the target (sounded) stimuli. The Russian and English sentences were practically identical semantically and contained iconic words that were either sound imitative (example A) or sound symbolic with pejorative or meliorative connotation (example B). These were extracted from the English iconic vocabulary dictionary (ФАаксман 2016) or the author's corpus of Russian and American expressive slang terms. More than 4300 responses were elicited and analysed and the data statistically evaluated.

\section{Results and discussion}

The high percentage of correct choices made by the subjects in the experiments, as well as no cases of refusal to take part in them, definitely point to a cognitive potential of iconic lexis or, in other words, to its euristic function (Шамина 2018). It should also be noted that any observed discrepancies between reactions of respondents in different age and gender groups are statistically insignificant. 
The average correct identification and interpretation of the foreign language units under consideration varies from $70 \%$ for Russian sound imitations to $77 \%$ for English emotive slang words, peaking to $96 \%$ for certain items.

Thus, in respect to onomatopes, English speaking subjects in $87 \%$ of cases chose брякнуть / br'aknut'/ over жужнать /ZuZZat'/ to designate the sound of keys put into a pocket, and Russian speaking subjects prefered the English word rumble $/ \mathrm{r} \wp \mathrm{mbl} /$ to stutter / $\mathrm{st} \wp \mathrm{t} \cong \mathrm{r} /$ in the context of ... my stomach ... in anticipation of dinner in $91 \%$ of cases. Different classes of onomatopes (instants, continuants and frequentatives - cf. (Voronin 2005)) seem to demonstate certain tendencies in being recognized by speakers of other languages easier or with more difficulty. Instants, or imitations of pulses, comprise a group of words that are better recognized in both of the languages under study.

Speaking of sound symbolic items, pejoratives and melioratives demonstrate clear-cut phonetic forms that are perceived as such by speakers of the other language. For example, $96 \%$ of the Russian subjects preferred nerd $/ \mathrm{n} 3 \mathrm{rd} /$ to sunny $/ \mathrm{s} \wp \mathrm{nI} /$ as a pejorative, and English subjects did the same in respect to nентюо /p'ent'ux/ in contrast to дельный /d'el'nIj/ in $92 \%$ of cases. For some reason, pejoratives turned out to be easier recognized than melioratives.

The results in most cases can be accounted for by the well-established tendencies in language sounds representing non-linguistic acoustic phenomena (e.g. trills imitating vibrations) and non-acoustic notions (e.g. back rounded vowels standing for "bad" things, or labials and velars being "sound gestures" of dislike) that are supposed to be universal (Шамина 2013).

\section{Conclusion}

The data gained from the experiments described above can be interpreted in two ways. First, the results clearly demonstrate the possibility of a nonarbitrary link between the sound form of a (expressive) word and its meaning. Second, the specifically linguistic design of the experiments helps to avoid the influence of purely visual and non-linguistic acoustic factors on the outcome. This makes the evidence for non-arbitrary links between the sound form and the meaning of natural language units elicited in this way more valid linguistically.

\section{Acknowledgements}

The author is deeply grateful to Natalia Dmitrieva for her help in conducting the experiment.

\section{References}

Fodor, J.A. 1975.The Language of Thought. N.Y., Harvard University Press.

Köhler, W. 1929. Gestalt Psychology. New York, Liveright. 
Peirce, C. S. 1994. In Peirce on Signs: Writings on Semiotic. James Hoopes (ed.) 1994, Chapel Hill, NC, University of North Carolina Press. Perlman, M., Lupyan, G. 2018. People can create iconic vocalizations to communicate various meanings to native listners. Scientific Reports 8 (1), 2634.

Syles, S., Gawne, L. 2017. When Does Maluma/Takete Fail? Two Key Failures and a Meta-Analysis Suggest That Phonology and Phonotactics Matter. I-Perception 8 (4), 2041669517724807.

Osgood, C.T., Suci, G.J., Tannenbaum, P.H. 1967. The Measurement of Meaning. Urbana, University of Illinois Press.

Voronin, S.V. 2005. The Universal Classification of Onomatopes 25 Years On. In Iconicity. Glottogenesis. Semiosis. St.Petersburg, St.Petersburg State University Press. $30-37$.

Воронин С.В. 1982.Основы фоносемантики. АенинграА, ИзА-во АГУ. Горелов И.Н. 2003. Проблема функционального базиса речи в онтогенезе. In Избранные труды по психолингвистике. Москва, Аабиринт, 15-104.

Журавлев А.П. 1974. Фонетическое значение. Аенинград, ИзА-во АГУ. ФАаксман М. А. 2016. Словарь английской звукоизобразительной мексики в Аиахроническом освещении. СПб., Издательство РХГА.

Шамина Е.А. 2013. Восприятие эмоционально-оценочной мексики неродного языка: универсальные и частноязыковые факторы. In Proc. $10^{\text {th }}$ International Congress of the International Society of Applied Psycholinguistics. 272-273. Moscow, Russia.

Шамина Е.А. 2018. Когнитивная валентность звукоподражательной мексики (экспериментальное исследование). In Когнтивные исследования языка, XXXIY. Cognitio и Communicatio в современном глобальном мире. Москва - Тамбов, Ин-т языкознания РАН, 338-342. 